\title{
Nitrogen use and rice yield formation response to zeolite and nitrogen coupling effects: Enhancement in nitrogen use efficiency
}

\author{
Qi Wu${ }^{1}$, Guimin $\mathrm{Xia}^{1 *}$, Taotao Chen ${ }^{1}$, Xuan Wang ${ }^{1}$, Daocai Chi ${ }^{1 *}$, Dehuan Sun $^{2}$ \\ ${ }^{1}$ College of Water Resource, Shenyang Agricultural University, Shenyang, Liaoning 110866, P.R. China \\ ${ }^{2}$ Experimental Irrigation Station, Water Conservancy Bureau of Donggang city, Dandong, Liaoning 118000, \\ P.R.China. "Corresponding author: daocaichi@vip.sina.com \& xiagm1229@126.com
}

These authors contributed equally to this work.

\begin{abstract}
Objective of the article was to assess the coupling effects of zeolite $\left(\mathrm{Z}_{0}, 0 \mathrm{tha}^{-1} ; \mathrm{Z}_{0.9}\right.$ and $\mathrm{Z}_{0.22}, 10 \mathrm{tha} \mathrm{h}^{-1}$ in different diameter of 0.45-0.9 mm and 0.17-0.22 mm) and Nitrogen $\left(\mathrm{N}_{0}, \mathrm{~N}_{52.5}, \mathrm{~N}_{105}, \mathrm{~N}_{157.5} \mathrm{~kg} \mathrm{ha}^{-1}\right)$ application on $\mathrm{N}$ use, leaf area index (LAI) and rice grain yield in 2014 and 2015. Results showed that both $\mathrm{Z}_{0.9}$ and $\mathrm{Z}_{0.22}$ at $\mathrm{N}_{105}$ and $\mathrm{N}_{157.5}$ application rates could greatly enhance the biomass, dry weight of root, LAI and N uptake. However, at initial tillering stage of rice, $\mathrm{Z}$ decreased $\mathrm{N}$ content in plant for its high absorption capacity and hence lowered biomass and $\mathrm{N}$ uptake. The highest value of $N$ recovery efficiency (NRE) and $N$ use efficiency (NUE) was obtained from $N_{105} Z_{0.22}$. $\mathrm{Z}$ input contributed to higher NRE and NUE. At $\mathrm{N}_{157.5}$ application rate, $\mathrm{Z}_{0.9}$ and $\mathrm{Z}_{0.22}$ significantly increased rice grain yield by $14.6 \%$ and $15.3 \%$, respectively. However, $\mathrm{Z}$ mattered little to rice grain yield at $\mathrm{N}_{0}$ and $\mathrm{N}_{52.5}$. There was no significant difference in rice grain yield between $\mathrm{Z}_{0.22}$ and $\mathrm{Z}_{0.9} \cdot \mathrm{Z}_{0.22}$ and $\mathrm{Z}_{0.9}$ clearly increased the 1000 -grain weight. $\mathrm{N}$ application significantly lowered unfilled grain percentage and 1000-grain weight.
\end{abstract}

Keywords: Nitrogen use, zeolite, coupling effect, root, nitrogen uptake

\section{Introduction}

Rice consumed to provide $20-21 \%$ of total calories is the staple and required food of more than $50 \%$ of the world population (Fageria, 2007; Sandhu et al., 2012; Fitzgerald et al., 2009). In China, rice is the major contributor to total food yield and its yield accounts for $40 \%$ of total domestic grain production.
With decreasing in cultivated land area in China since 1992, enhancing the rice grain yield per unit should be emphasized greatly (FAO, 2016).

The mix of zeolite $(\mathrm{Z})$ and nitrogen $(\mathrm{N})$ has been investigated to enhance soil fertility and improve crop production. Ippolito and Tarkalson (2011) applied 
$\mathrm{Z}\left(0,6.7,13.4,20.2\right.$, and $\left.26.9 \mathrm{Mg} \mathrm{ha}^{-1}\right)$ to Portneuf silt loam and Wolverine sand soils, noting that rates of 6.7 to $13.4 \mathrm{Mg} \mathrm{ha}^{-1}$ conserved inorganic $\mathrm{N}$ and resulted in higher $\mathrm{N}$ use. When paddy soil was exposed to the late season drought stress, application rate of $10 \mathrm{t} \mathrm{Z} \mathrm{ha-1}$ that could promote water retention was helpful for yield improvement and prevention of decreasing yield, but these effects were not obvious under conditions of complete irrigation (Zahedi et al., 2009). According to Lija et al. (2013), low application rates of $Z$ would cause better $N$ use efficiency (NUE) compared to higher application rates. Kavoosi (2007) mixed $\mathrm{Z}\left(8,16\right.$, and $\left.24 \mathrm{t} \mathrm{ha}^{-1}\right)$ and $\mathrm{N}\left(60 \mathrm{~kg} \mathrm{ha}^{-1}\right)$ into paddy soil and found that rice grain yield showed a decline trend with the increase of $\mathrm{Z}$ application rates. These researches indicated that under different environment conditions, performance of $\mathrm{Z}$ application in crop production was different. In other words, there may be interaction effects on crop production between $\mathrm{Z}$ and irrigation regimes or $\mathrm{N}$ application rates. However, the scientific researches were rare on interaction effects between $\mathrm{Z}$ and $\mathrm{N}$.

Roots are an integral part of plant organs and involved in acquisition of water and nutrients. The morphology of root is closely associated with the development of aboveground part of plant growth (Shen et al., 2016). Sepaskhah and Barzegar (2010) demonstrated that Z application plus $\mathrm{N}$ which is comparable to the slowrelease $\mathrm{N}$ fertilizer greatly enhanced the $\mathrm{N}$ uptake by plant. The application of slow-release fertilizer could clearly improve root bleeding intensity during early to middle stage of rice growth and resulted in higher physiological function of rice root system (Tang et al., 2007). Similar result was also found by Zhang et al. (2013) and he indicated that the slow-release fertilizer based on biochar significantly increased main root length and fresh weight of rice roots which led to enlarged root absorption area, higher root physiological activity and rice grain yield. However, there was little information on rice root with the application of $\mathrm{Z}$ with $\mathrm{N}$.

Therefore, the objectives of this experiment were to investigate the interaction effects between $\mathrm{Z}$ and $\mathrm{N}$ application on rice grain yield, root dry weight, Leaf area index (LAI), N uptake, NUE and N recovery efficiency (NRE) to underline the significance of $\mathrm{Z}$ application strategies under different soil fertility grads in two growth seasons of 2014 and 2015 in northeast coastal region of China. Z was only applied in 2014 and no additional $\mathrm{Z}$ was applied in 2015 .

\section{Materials and Methods}

\subsection{Site description}

The experiment was conducted from May 2014 to October 2015 at Donggang experimental irrigation station $\left(40^{\circ} 22^{\prime} \mathrm{N}\right.$ latitude, $113^{\circ} 33^{\prime} \mathrm{E}$ longitude and altitudes of $8.1 \mathrm{~m}$ ). The area belongs to continental moist monsoon climatic region of temperate zone. It is affected by the Yellow Sea and characterized by the maritime climate. Its average annual air temperature is $8.4{ }^{\circ} \mathrm{C}$. The yearly average precipitation which is mostly concentrated in the summer months is 967 $\mathrm{mm}$. Physical and chemical properties of soil used in the two-year experiment are shown in Table1. According to Table 1, the soil texture was silty clay loam.

Table 1. Physical and chemical properties of experimental soil

\begin{tabular}{lc}
\hline Soil properties & Content \\
\hline Sand (\%) & 11.4 \\
Silt (\%) & 66.7 \\
Clay (\%) & 21.9 \\
pH & 6.76 \\
Bulk density $\left(\mathrm{g} \mathrm{cm}^{-3}\right)$ & 1.4 \\
Available P $\left(\mathrm{mg} \mathrm{kg}^{-1}\right)$ & 32.33 \\
Available K $\left(\mathrm{mg} \mathrm{kg}^{-1}\right)$ & 56.56 \\
Alkali-hydrolysable N $\left(\mathrm{mg} \mathrm{kg}^{-1}\right)$ & 36.55 \\
Total N $\left(\mathrm{g} \mathrm{kg}^{-1}\right)$ & 0.677 \\
Organic matter $\left(\mathrm{g} \mathrm{kg}^{-1}\right)$ & 9.02 \\
\hline
\end{tabular}




\subsection{Treatments and design}

Field experiment in 2014 and 2015 was designed as a split plot design with 3 replications. $\mathrm{N}$ application rates $\left(\mathrm{N}_{0}, \mathrm{~N}_{52.5}, \mathrm{~N}_{105}, \mathrm{~N}_{157.5} \mathrm{~kg} \mathrm{ha}^{-1}\right)$ were the main plots. Z application rates were the subplots and the particle sizes were in the following ranges: $\mathrm{Z}_{0}, 0 \mathrm{tha} \mathrm{h}^{-1} ; \mathrm{Z}_{0.9}$ and $\mathrm{Z}_{0.22}$, $10 \mathrm{t} \mathrm{ha}^{-1}$ in different diameter of $0.45-0.9 \mathrm{~mm}$ and 0.17 $0.22 \mathrm{~mm}$, respectively. Chen et al. (2014) found that $\mathrm{Z}$ application rate of $10 \mathrm{tha}^{-1}$ could significantly increase rice grain yield in this region under traditional $\mathrm{N}$ regimes. Therefore, $\mathrm{Z}$ was applied at application rate of $10 \mathrm{tha}^{-1}$ in the experiment.

The natural $\mathrm{Z}$ used in this study originated from Liaoning province, China. $\mathrm{Z}$ had the following chemical composition (in \%): $\mathrm{SiO}_{2}=65.56, \mathrm{Al}_{2} \mathrm{O}_{3}=10.62, \mathrm{Na}_{2} \mathrm{O}=0.39$, $\mathrm{K}_{2} \mathrm{O}=2.87, \mathrm{CaO}=2.59, \mathrm{Fe}_{2} \mathrm{O}_{3}=0.63, \mathrm{MgO}=0.82, \mathrm{FeO}$ $=0.09, \mathrm{TiO}_{2}=0.069, \mathrm{P}_{2} \mathrm{O}_{5}=0.001, \mathrm{MnO}=0.01, \mathrm{H}_{2} \mathrm{O}=8.16$, and Loss of Ignition $(\mathrm{LOI})=16.59$. $\mathrm{Z}$ was applied and incorporated into near-surface $(0-30 \mathrm{~cm})$ soil as basal fertilizer with $\mathrm{N}$. Based on the traditional fertilization method in the experimental station, $\mathrm{N}$ (urea) was applied into near-surface soil layer in three parts: 60\% basal, 30\% 10 days after transplanting and $10 \% 15$ days after jointingbooting stage, respectively. $\mathrm{K}\left(\mathrm{K}_{2} \mathrm{O}, 72 \mathrm{~kg} \mathrm{ha}^{-1}\right)$ was applied as potassium sulfate in two parts: $50 \%$ basal and $50 \% 15$ days after jointing-booting stage, respectively. $\mathrm{P}$ $\left(\mathrm{P}_{2} \mathrm{O}_{5}, 172 \mathrm{~kg} \mathrm{ha}^{-1}\right)$ was all applied as the basal fertilizer. The traditional variety used in the experimental station was Gangyu6 (Japonica rice) both in the two years. Days of sowing begins in 22th April, transplanting in 28th May, respectively. Seeding recovery stage (S) begins in 29th May, tillering stage ( $\mathrm{T}$ ) in 5th June, jointing-booting stage (J) in 4-6th July, heading-flowering stage $(\mathrm{H})$ in 3-7th August, milky ripening stage (M) in 23-28th August, yellow ripening stage $(\mathrm{Y})$ in 5-10th September and rice harvest in 16-20th September, respectively. Each hill had 3 rice seedlings ( 7 x 17-hills per plot). Plot sizes were 2.5 x $2-\mathrm{m}^{2}$ and rice was transplanted at $14 \times 30-\mathrm{cm}$ spacing. Plots were regularly hand-weeded and pesticides were used to prevent insect and pest damage. No noticeable crop damage was observed in the experiment. The water layer in these plots was maintained at $1-7 \mathrm{~cm}$ in the whole growth stages of rice. Water was distributed by pipe to each plot for irrigation. Water depth was measured on a permanently fixed depth gauge. Excessive water was drained off through flumes if there was a heavy rainfall. Irrigation water was stopped 15 days before harvest.

\subsection{Samples measurements}

Crop samples for biomass, $\mathrm{N}$ uptake and LAI were taken 4-5 times from transplanting onward. In 2014, the sampling days were respectively on 6th June in tillering stage, 12th July in jointing-booting stage, 8th August in heading-flowering stage, 2nd September in milky ripening stage and 18th September in yellow ripening stage. In 2015, the sampling days were 22th June, 5th July, 6th August, 26th August and 15th September, respectively. At each sampling, 2 hills per plot with 3 replications were pulled out, separated and rinsed. The dry weight of the plant was determined after drying at $75{ }^{\circ} \mathrm{C}$ until constant weight was reached. The LAI was determined by Plant Canopy Analyzer LICOR, model-2000.

At the end of growth stage, rice grain yield was calculated based on $14 \%$ moisture content. The number of panicles was counted from randomly selected three plants and the weight of grains per panicle was calculated by weighting method. The unfilled grain percentage and 1000-grain weight were determined after the process of drying and enzyme deactivation. The total $\mathrm{N}$ content in leaf, stem and grain (LNC, SNC and GNC) was determined by the semi-micro Kjeldahl method (Shi and Bao, 1996).

\subsection{Nitrogen use}

$\mathrm{N}$ uptake was calculated using

$\mathrm{N}$ uptake $=\mathrm{NC} \times \mathrm{DW}$ 
Where, NC is the nitrogen content in plant $\left(\mathrm{g} \mathrm{kg}^{-1}\right)$, DW is the dry weight of plant $(\mathrm{kg})$.

NRE was calculated using

$$
\mathrm{NRE}=\left(\mathrm{U}-\mathrm{U}_{\mathrm{o}}\right) / \mathrm{FN}
$$

Where, NRE is the nitrogen recovery efficiency, $\mathrm{U}$ and $\mathrm{U}_{0}$ are the total $\mathrm{N}$ uptake by grain, stem and leaf in different $\mathrm{N}$ and $\mathrm{Z}$ treatments and control, respectively in $\mathrm{kg} \mathrm{ha}^{-1}$. FN $\left(\mathrm{kg} \mathrm{ha}^{-1}\right)$ is the applied $\mathrm{N}$ as fertilizer in different $\mathrm{N}$ treatments.

$$
\mathrm{NUE}=\left(\mathrm{N}_{\mathrm{y}}-\mathrm{N}_{\mathrm{o}}\right) / \mathrm{FN}
$$

Where NUE is the nitrogen use efficiency, $\mathrm{N}_{\mathrm{Y}}$ and $\mathrm{N}_{0}$ $\left(\mathrm{kg} \mathrm{ha}^{-1}\right)$ are the $\mathrm{N}$ uptake by rice grain in different treatments and control. FN expressed in $\mathrm{kg} \mathrm{ha}^{-1}$ is the applied $\mathrm{N}$ as fertilizer in different $\mathrm{N}$ treatments.

\subsection{Statistical analysis of the data}

All data (two-year mean) were subjected to analysis of variance (ANOVA) using SAS9.3 software. Bartlett's test showed homogeneity of variance in all terms. When an F-test indicated statistical significance at $\mathrm{P}<0.05$, the Duncan method was used to separate the means of main effect and the interaction effect.

\section{Results}

\subsection{Crop growth and dry weight of root}

According to Figure 1, differences between $\mathrm{Z}$ treatments at different application rates of $\mathrm{N}$ in crop growth were large while at $\mathrm{N}_{0}$ and $\mathrm{N}_{52.5}$ application rates, there were small differences in biomass between $\mathrm{Z}$ treatments. At application rates of $\mathrm{N}_{105}$ and $\mathrm{N}_{157.5}$, treatment of $\mathrm{Z}$ resulted in higher biomass at harvest. However, $\mathrm{Z}$ application led to weak crop growth at the initiation of rice growth stage according to the drawing of partial enlargement in Figure 1. There were relatively small differences in biomass between different particle sizes of $\mathrm{Z}$ and $\mathrm{N}$ mattered greatly to the biomass.

There were no significant interaction effects between $\mathrm{N}$ and $\mathrm{Z}$ application on dry weight of root in Table 2. The increase of dry weight of root affected by $\mathrm{N}$ was significant. There were small differences in dry weight of root between $\mathrm{Z}$ treatments at application rate of $\mathrm{N}_{0}$ and $\mathrm{N}_{52.5}$. However, $\mathrm{Z}$ seemed to significantly enlarge the root at application rates of $\mathrm{N}_{105}$ and $\mathrm{N}_{157.5}$. Different particle sizes of $\mathrm{Z}$ mattered little to dry weight of root. It indicated that a strong deep rice root system may greatly contribute to the rice aboveground biomass development.

Table 2. Analysis of variance of $\mathrm{N}$ and $\mathrm{Z}$ effects on different indices of rice

\begin{tabular}{lccccccccc}
\hline $\begin{array}{l}\text { Source of } \\
\text { variance }\end{array}$ & $\begin{array}{c}\text { Grain } \\
\text { yield }\end{array}$ & $\begin{array}{c}1000 \text {-grain } \\
\text { weight }\end{array}$ & UGP & GNC & SNC & LNC & $\begin{array}{c}\text { Dry } \\
\text { weight } \\
\text { of root }\end{array}$ & NRE & NUE \\
\hline Block & $0.26^{\text {ns }}$ & $3.84^{\text {ns }}$ & $1.04^{\text {ns }}$ & $1.15^{\text {ns }}$ & $0.63^{\text {ns }}$ & $1.04^{\text {ns }}$ & $0.20^{\text {ns }}$ & $7.01^{\text {ns }}$ & $7.09^{\text {ns }}$ \\
$\mathrm{N}$ & $653.15^{* *}$ & $186.08^{* *}$ & $9.19^{* *}$ & $227.27^{* *}$ & $51.17^{* *}$ & $52.54^{* *}$ & $106.01^{* *}$ & $26.91^{* *}$ & $2.65^{\text {ns }}$ \\
$\mathrm{N}^{*}$ Block & $1.54^{\text {ns }}$ & $1.40^{\text {ns }}$ & $2.67^{\text {ns }}$ & $1.36^{\text {ns }}$ & $2.26^{\text {ns }}$ & $2.69^{\text {ns }}$ & $0.90^{\text {ns }}$ & $0.98^{\text {ns }}$ & $0.29^{\text {ns }}$ \\
$\mathrm{Z}$ & $86.98^{* *}$ & $102.88^{* *}$ & $0.06^{\text {ns }}$ & $2.02^{\text {ns }}$ & $13.87^{* *}$ & $22.52^{* *}$ & $2.18^{\text {ns }}$ & $61.8^{* *}$ & $45.18^{* *}$ \\
$\mathrm{~N}^{*} Z$ & $26.96^{* *}$ & $1.19^{\text {ns }}$ & $0.72^{\text {ns }}$ & $5.28^{* *}$ & $0.94^{\text {ns }}$ & $2.05^{\text {ns }}$ & $1.58^{\text {ns }}$ & $14.29^{* *}$ & $1.83^{\text {ns }}$ \\
Root & 0.10 & 0.073 & 0.82 & 0.11 & 0.08 & 0.10 & 0.278 & 1.22 & 0.97 \\
MSE & 1.76 & 0.272 & 17.38 & 1.51 & 5.62 & 2.85 & 7.445 & 3.16 & 3.92 \\
CV.\% & & & & & & & & & \\
\hline
\end{tabular}

Note: "Significant at the 0.05 probability level; ${ }^{* *}$ Significant at the 0.01 probability level. ${ }^{\text {ns }}$ non-significant. Hypotheses test for Block and $\mathrm{N}$ using Block*N as an error term. UGP, GNC, SNC, LNC: unfilled grain percentage, nitrogen content in grain, stem and leaf, respectively; NRE and NUE: nitrogen recovery efficiency and nitrogen use efficiency 


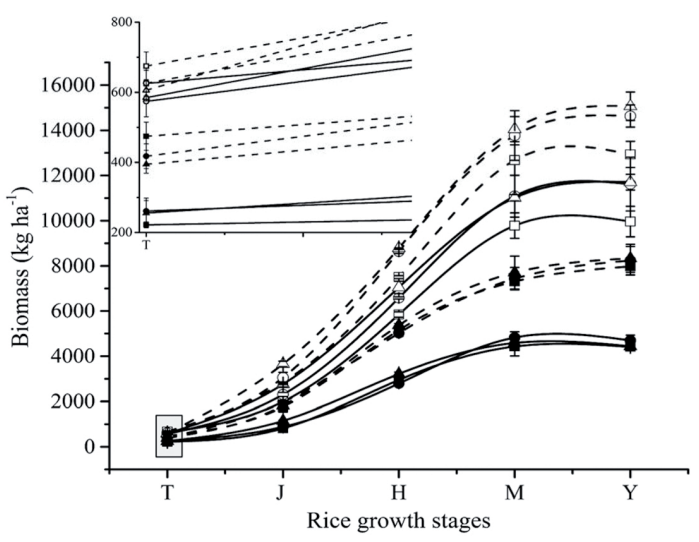

Figure 1. Biomass changes at different rice growth stages at $\mathrm{N}$ levels of $\mathrm{N}_{0}, \mathrm{~N}_{105}(-)$ and $\mathrm{N}_{52.5}, \mathrm{~N}_{157.5}(--$ -), Z levels of $Z_{0}(\bullet, \square), Z_{0.9}(\bullet, \circ), Z_{0.22}(\boldsymbol{\Delta}, \Delta)$; T, J, $\mathrm{H}, \mathrm{M}$ and $\mathrm{Y}$ are the tillering stage, jointing-booting stage, heading-flowering stage, milky ripening stage and yellow ripening stage, respectively; bars is the standard error.

\subsection{Leaf area index}

Differences between $\mathrm{Z}$ treatments at different application rates of $\mathrm{N}$ on LAI were large according to Figure 2. At $\mathrm{N}_{0}$ and $\mathrm{N}_{52.5}$ application rates, there were small differences in LAI between $\mathrm{Z}$ treatments. However, at application rates of $\mathrm{N}_{105}$ and $\mathrm{N}_{157.5}$, treatment of $\mathrm{Z}$ clearly affected the LAI. There were relatively small differences in LAI between different particle sizes of $\mathrm{Z}$ while $\mathrm{N}$ input greatly increased LAI. The maximum LAI in the experiment was 4.15 with the treatment of small particle size of $\mathrm{Z}_{0.22}$ at $\mathrm{N}_{157.5}$ application rate. Treatments of $Z$ revealed more significant effects on LAI at jointing-booting stage and heading-flowering stage. It indicated that the enhanced LAI could improve the rate of photosynthesis of rice and increase drought resistance.

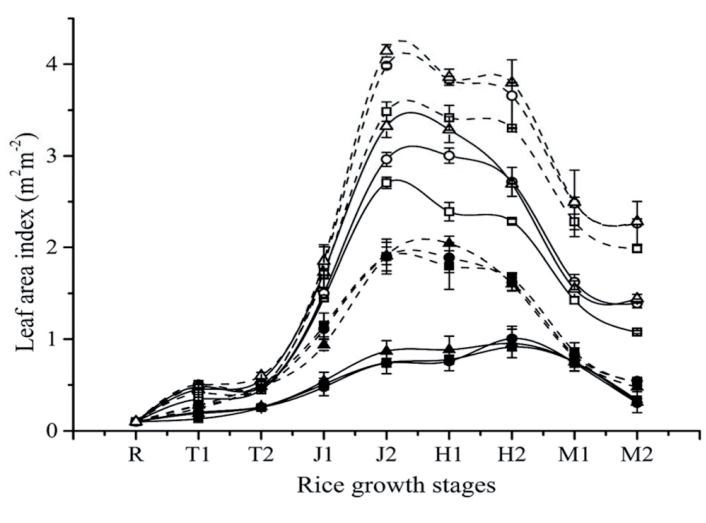

Figure 2. LAI changes at different rice growth stages at $\mathrm{N}$ levels of $\mathrm{N}_{0}, \mathrm{~N}_{105}(-)$ and $\mathrm{N}_{52.5}, \mathrm{~N}_{157.5}(--$ -), Z levels of $\mathrm{Z}_{0}(\boldsymbol{\bullet}, \square), \mathrm{Z}_{0.9}(\bullet, \circ), \mathrm{Z}_{0.22}(\boldsymbol{\Delta}, \Delta)$; R, $\mathrm{T}, \mathrm{J}, \mathrm{H}$ and $\mathrm{M}$ are the recovery stage, tillering stage, jointing-booting stage, heading-flowering stage and milky ripening stage, respectively; bars is the standard error.

\subsection{Nitrogen uptake and Nitrogen content in plant}

Figure 3 showed $\mathrm{N}$ accumulation at various growth stages of rice in both the two growing seasons. With treatments of $\mathrm{N}$ plus $\mathrm{Z}, \mathrm{N}$ uptake of rice at tillering stage was less than those of $\mathrm{N}$ treatments without $\mathrm{Z}$ application, which was obviously contrary to that behind tillering stage based on the drawing of partial enlargement in Figure 3. At $\mathrm{N}_{105}$ and $\mathrm{N}_{157.5}$ application rates, $\mathrm{Z}$ treatments showed higher $\mathrm{N}$ accumulation from jointing-booting stage to yellow ripening stage. $\mathrm{Z}$ mattered little to $\mathrm{N}$ uptake at application rates of $\mathrm{N}_{0}$ and $\mathrm{N}_{52.5}$. The highest $\mathrm{N}$ uptake of the rice at yellow ripening stage was 69.22 at $\mathrm{N}_{105}$ and $84.23 \mathrm{~kg} \mathrm{ha}^{-1}$ at $\mathrm{N}_{157.5}$ with treatments of $\mathrm{Z}_{0.22}$ - which was respectively $18.9 \%, 11.3 \%$ higher than that of $\mathrm{N}$ treatments without $\mathrm{Z}$. 


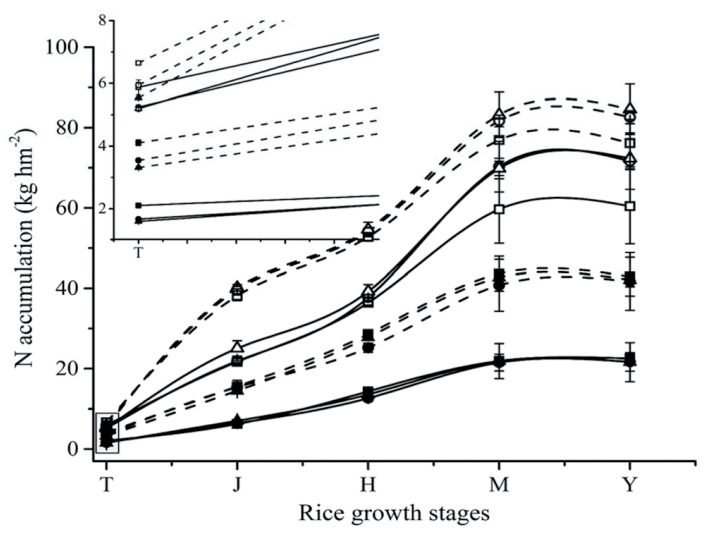

Figure 3. $\mathrm{N}$ accumulation at different rice growth stages at $\mathrm{N}$ levels of $\mathrm{N}_{0}, \mathrm{~N}_{105}(-)$ and $\mathrm{N}_{52.5}, \mathrm{~N}_{157.5}(--)$, Z levels of $\mathrm{Z}_{0}(\boldsymbol{\square}, \square), \mathrm{Z}_{0.9}(\bullet, \circ), \mathrm{Z}_{0.22}(\boldsymbol{\Delta}, \Delta)$; T, J, H, M and Y are the tillering stage, jointing-booting stage, headingflowering stage, milky ripening stage and yellow ripening stage, respectively; bars is the standard error.
$\mathrm{N}$ and $\mathrm{Z}$ enhancement resulted in significant increase and slight decrease in rice SNC and LNC according to Table 4. Z clearly lowered $\mathrm{N}$ content in GNC at $\mathrm{N}_{0}$ and $\mathrm{N}_{52.5}$ which was completely contrary to that at $\mathrm{N}_{105}$ and $\mathrm{N}_{157.5}$. It indicated that higher $\mathrm{N}$ input could alleviate $\mathrm{N}$ stress by $\mathrm{Z}$ for its high $\mathrm{NH}_{4}^{+}$absorption capacity. Thereby, $\mathrm{Z}$ application enhanced the rice $\mathrm{N}$ content in grain at $\mathrm{N}_{105}$ and $\mathrm{N}_{157.5}$. Figure 3 also revealed that $\mathrm{N}$ stress affected by $\mathrm{Z}$ led to a decrease in SNC and LNC may mainly happen in tillering stage based on high absorption capacity of $\mathrm{Z}$ and in reproductive period $\mathrm{Z}$ significantly enhanced $\mathrm{N}$ content in grain according to the slow-release function of $\mathrm{Z}$.

Table 4. Interaction effects and main effects between $\mathrm{Z}$ and $\mathrm{N}$ application on different indices of rice

\begin{tabular}{|c|c|c|c|c|}
\hline \multirow{2}{*}{$\mathrm{N}$ levels } & \multicolumn{3}{|c|}{$\mathrm{Z}$ levels } & \multirow{2}{*}{$\mathrm{N}$ main effec } \\
\hline & $Z_{0}$ & $\mathrm{Z}_{0.9}$ & $\mathrm{Z}_{0.22}$ & \\
\hline \multicolumn{5}{|l|}{ GNC $\left(\mathrm{mg} \mathrm{g}^{-1}\right)$} \\
\hline $\mathrm{N}_{0}$ & $6.47 \mathrm{e}$ & $6.18 \mathrm{f}$ & $6.13 \mathrm{f}$ & $6.26 \mathrm{~d}$ \\
\hline $\mathrm{N}_{52.5}$ & $6.93 \mathrm{c}$ & $6.71 \mathrm{~d}$ & $6.67 \mathrm{~d}$ & $6.77 \mathrm{c}$ \\
\hline $\mathrm{N}_{105}$ & $7.33 b$ & $7.36 \mathrm{~b}$ & $7.44 b$ & $7.38 b$ \\
\hline $\mathrm{N}_{157.5}$ & $7.52 \mathrm{ab}$ & $7.71 \mathrm{a}$ & $7.70 \mathrm{a}$ & $7.64 \mathrm{a}$ \\
\hline $\mathrm{Z}$ main effect & $7.06 \mathrm{a}$ & $6.99 a$ & $6.98 \mathrm{a}$ & \\
\hline \multicolumn{5}{|l|}{$\mathrm{LNC}\left(\mathrm{mg} \mathrm{g}^{-1}\right)$} \\
\hline $\mathrm{N}_{0}$ & 3.16 & 3.00 & 3.07 & $3.07 \mathrm{c}$ \\
\hline $\mathrm{N}_{52.5}$ & 3.59 & 3.25 & 3.20 & $3.35 b$ \\
\hline $\mathrm{N}_{105}$ & 3.87 & 3.76 & 3.67 & $3.77 \mathrm{a}$ \\
\hline $\mathrm{N}_{157.5}$ & 3.96 & 3.78 & 3.92 & $3.89 \mathrm{a}$ \\
\hline $\mathrm{Z}$ main effect & $3.65 \mathrm{a}$ & $3.45 b$ & $3.47 \mathrm{~b}$ & \\
\hline \multicolumn{5}{|l|}{$\mathrm{SNC}\left(\mathrm{mg} \mathrm{g}^{-1}\right)$} \\
\hline $\mathrm{N}_{0}$ & 1.02 & 0.96 & 0.96 & $0.98 \mathrm{~d}$ \\
\hline $\mathrm{N}_{52.5}$ & 1.47 & 1.23 & 1.28 & $1.33 \mathrm{c}$ \\
\hline $\mathrm{N}_{105}$ & 1.59 & 1.54 & 1.49 & $1.55 \mathrm{~b}$ \\
\hline $\mathrm{N}_{157.5}$ & 1.91 & 1.86 & 1.81 & $1.86 \mathrm{a}$ \\
\hline $\mathrm{Z}$ main effect & $1.50 \mathrm{a}$ & $1.40 \mathrm{~b}$ & $1.39 \mathrm{~b}$ & \\
\hline \multicolumn{5}{|l|}{ NRE $(\%)$} \\
\hline $\mathrm{N}_{0}$ & I & I & I & l \\
\hline $\mathrm{N}_{52.5}$ & $37.05 b c$ & $38.37 b$ & $38.27 \mathrm{~b}$ & $37.89 \mathrm{~b}$ \\
\hline $\mathrm{N}_{105}$ & $34.12 \mathrm{c}$ & $44.25 \mathrm{a}$ & $44.82 \mathrm{a}$ & $41.06 \mathrm{a}$ \\
\hline $\mathrm{N}_{157.5}$ & $33.82 \mathrm{c}$ & $38.27 b$ & $39.21 b$ & $37.10 \mathrm{~b}$ \\
\hline $\mathrm{Z}$ main effect & $34.99 \mathrm{~b}$ & $40.29 a$ & $40.77 \mathrm{a}$ & \\
\hline \multicolumn{5}{|l|}{ NUE $(\%)$} \\
\hline $\mathrm{N}_{0}$ & / & / & / & I \\
\hline $\mathrm{N}_{52.5}$ & 24.07 & 25.01 & 25.69 & $24.92 \mathrm{a}$ \\
\hline $\mathrm{N}_{105}$ & 21.71 & 26.41 & 27.17 & $25.10 \mathrm{a}$ \\
\hline $\mathrm{N}_{157.5}$ & 22.26 & 25.24 & 26.12 & $24.54 \mathrm{a}$ \\
\hline$Z$ main effect & $22.35 b$ & $25.89 \mathrm{a}$ & $26.33 \mathrm{a}$ & \\
\hline
\end{tabular}




\subsection{Yield and yield components}

There were significant interaction effects on average of rice grain yield between $\mathrm{N}$ and $\mathrm{Z}$ application rates over the two years in Table 2. According to Table 3, at application rates of $\mathrm{N}_{0}$ and $\mathrm{N}_{52.5}$, rice grain yield did not vary greatly with treatments of $Z$; it was significantly increased by $\mathrm{Z}$ at application rates of $\mathrm{N}_{105}$ and $\mathrm{N}_{157.5}$, but there were no considerable changes in rice grain yield between $\mathrm{Z}_{0.9}$ and $\mathrm{Z}_{0.22}$. Enhanced $\mathrm{N}$ fertilizer application significantly improved the rice grain yield. At $\mathrm{N}_{105}$ and $\mathrm{N}_{157.5}, \mathrm{Z}_{0.9}$ and $\mathrm{Z}_{0.22}$ significantly increased rice grain yield by $10.4 \%, 9.2 \%$ and
$14.6 \%, 15.3 \%$, respectively. According to interaction effect analysis in Table 3, $\mathrm{N}_{105}$ plus $\mathrm{Z}$ had a similar effect to $\mathrm{N}_{157.5}$ without $\mathrm{Z}$ on grain yield, which greatly decreased the applied $\mathrm{N}$ by $33 \%$. There was no significant interaction effect between $\mathrm{N}$ and $\mathrm{Z}$ application rates on average 1000-grain weight and unfilled grain percentage. Higher $\mathrm{N}$ application rates resulted in lower unfilled grain percentage. However, $\mathrm{Z}$ did not affect the unfilled grain percentage. Results in Table 3 showed that application of $\mathrm{Z}$ especially $\mathrm{Z}_{0.22}$ significantly increased the 1000 -grain weight, but the enhanced $\mathrm{N}$ application from 0 to $157.5 \mathrm{~kg} \mathrm{ha}^{-1}$ resulted in a decline trend in 1000-grain weight.

Table 3. Interaction effects and main effects between $\mathrm{Z}$ and $\mathrm{N}$ application on different indices of rice

\begin{tabular}{|c|c|c|c|c|}
\hline \multirow{2}{*}{$\mathrm{N}$ levels } & \multicolumn{3}{|c|}{$Z$ levels } & \multirow{2}{*}{$\mathrm{N}$ main effect } \\
\hline & $\mathrm{Z}_{0}$ & $\mathrm{Z}_{0.9}$ & $\mathrm{Z}_{0.22}$ & \\
\hline \multicolumn{5}{|c|}{$\begin{array}{l}\text { Dry weight of Root } \\
\text { (g) }\end{array}$} \\
\hline $\mathrm{N}_{0}$ & 2.51 & 2.62 & 2.54 & $2.56 \mathrm{~d}$ \\
\hline $\mathrm{N}_{52.5}$ & 3.66 & 3.44 & 3.51 & $3.53 \mathrm{c}$ \\
\hline $\mathrm{N}_{105}$ & 3.97 & 4.46 & 4.23 & $4.22 b$ \\
\hline $\mathrm{N}_{157.5}$ & 4.25 & 4.77 & 4.84 & $4.62 \mathrm{a}$ \\
\hline $\mathrm{Z}$ main effect & $3.60 \mathrm{a}$ & $3.82 \mathrm{a}$ & $3.78 \mathrm{a}$ & \\
\hline \multicolumn{5}{|c|}{ Grain yield $\left(\mathrm{t} \mathrm{ha}^{-1}\right)$} \\
\hline $\mathrm{N}_{0}$ & $3.26 \mathrm{e}$ & $3.14 \mathrm{e}$ & $3.18 \mathrm{e}$ & $3.19 \mathrm{~d}$ \\
\hline $\mathrm{N}_{52.5}$ & $4.43 \mathrm{~d}$ & $4.65 \mathrm{~d}$ & $4.67 d$ & $4.58 \mathrm{c}$ \\
\hline $\mathrm{N}_{105}$ & $6.69 c$ & $7.39 \mathrm{~b}$ & $7.30 \mathrm{~b}$ & $7.12 \mathrm{~b}$ \\
\hline $\mathrm{N}_{157.5}$ & $7.45 b$ & $8.53 \mathrm{a}$ & $8.59 \mathrm{a}$ & $8.19 \mathrm{a}$ \\
\hline $\mathrm{Z}$ main effect & $5.46 \mathrm{~b}$ & $5.93 \mathrm{a}$ & $5.93 \mathrm{a}$ & \\
\hline \multicolumn{5}{|c|}{1000 -grain weight $(\mathrm{g})$} \\
\hline $\mathrm{N}_{0}$ & 26.91 & 27.10 & 27.34 & $27.12 \mathrm{a}$ \\
\hline $\mathrm{N}_{52.5}$ & 26.78 & 26.92 & 27.12 & $26.94 b$ \\
\hline $\mathrm{N}_{105}$ & 26.33 & 26.60 & 26.74 & $26.56 \mathrm{c}$ \\
\hline $\mathrm{N}_{157.5}$ & 25.97 & 26.28 & 26.49 & $26.25 \mathrm{~d}$ \\
\hline $\mathrm{Z}$ main effect & $26.50 \mathrm{c}$ & $26.72 b$ & $26.92 \mathrm{a}$ & \\
\hline \multicolumn{5}{|l|}{ UPG $(\%)$} \\
\hline $\mathrm{N}_{0}$ & 6.00 & 6.96 & 6.87 & $6.61 \mathrm{a}$ \\
\hline $\mathrm{N}_{52.5}$ & 4.72 & 4.83 & 4.42 & $4.66 \mathrm{~b}$ \\
\hline $\mathrm{N}_{105}$ & 4.46 & 3.67 & 4.05 & $4.06 \mathrm{~b}$ \\
\hline $\mathrm{N}_{157.5}$ & 3.39 & 3.51 & 3.62 & $3.51 \mathrm{~b}$ \\
\hline$Z$ main effect & $4.64 \mathrm{a}$ & $4.75 \mathrm{a}$ & $4.74 \mathrm{a}$ & \\
\hline
\end{tabular}

Note: Mean values followed by a different letter are significant at 0.05 probability level. UGP: unfilled grain percentage. 


\subsection{Nitrogen use efficiency and nitrogen recovery efficiency}

There was a significant interaction effect on NRE but no statistically significant interaction effect on NUE between $\mathrm{Z}$ and $\mathrm{N}$ application rates according to Table 2 over the two years. The average value of NRE was significantly higher at $\mathrm{N}_{105}$ application rate than that at other $\mathrm{N}$ application rates. Based on the interaction effects analysis in Table 4, higher NRE was observed at appropriate $\mathrm{N}$ application rates from $\mathrm{N}_{105}$ to $\mathrm{N}_{157.5}$. At $\mathrm{N}_{105}$ application rate, $\mathrm{Z}_{0.9}$ and $\mathrm{Z}_{0.22}$ significantly increased the NRE by $29.68 \%$ and $31.35 \%$, respectively. $\mathrm{N}$ application mattered little to NUE in Table 4, but at $\mathrm{N}_{105}$ application rate, $\mathrm{Z}_{0.9}$ and $\mathrm{Z}_{0.22}$ significantly increased the NUE by $21.65 \%$ and $25.12 \%$, respectively. It indicated that $\mathrm{Z}$ input could lower $\mathrm{N}$ losses to the environment by enhanced $\mathrm{N}$ uptake.

\section{Discussion}

\subsection{Effects of $Z$ and $N$ management on crop growth and leaf area index}

$\mathrm{N}$ nutrition has a substantial impact on the predisposition of plants by affecting the growth pattern, morphology and chemical composition of plants. Khan et al. (2011) conducted greenhouse experiment and found that LAI and plant height of soybean were significantly enhanced by $\mathrm{Z}$ application. However, overuse of $\mathrm{Z}$ could produce larger canopy which created shading effect that would reduce photosynthesis and affect the biomass development. Kavoosi (2007) concluded that $\mathrm{Z}$ application significantly increased $\mathrm{N}$ uptake, nucleic acid, amides and hence cell multiplication, which increased leaf area and rice plant height. It indicated that proper use of $\mathrm{Z}$ could increase nutrition uptake and enhance cell multiplication, then resulted in higher LAI and biomass. In this experiment,
$\mathrm{Z}$ application significantly enhanced rice LAI and biomass. However, in the initial rice growth period, $\mathrm{Z}$ decreased biomass and LAI because of lower content of available $\mathrm{N}$ in soil for high absorption capacity of Z (Majid et al., 2012). There was no significant difference in rice LAI and biomass between different particle sizes of $Z$. According to our research, it was recommended that $\mathrm{N}_{157.5}$ plus $\mathrm{Z}$ would enhance the LAI and biomass.

\subsection{Enhancement in rice grain yield}

The $\mathrm{N}$ application plus $\mathrm{Z}$ which was comparable to slow-release fertilizers played an important role in rice grain yield increasing (Sepaskhah and Barzegar, 2010). It was found that the successive release rate of $\mathrm{N}$ in $\mathrm{Z}$ exchange sites corresponded well to the $\mathrm{N}$ requirements of crops (Geng et al., 2015). And, treatment of slow-release fertilizer increasing rice grain yield may mainly due to (1) larger content of available $\mathrm{N}$ in soil to enhance $\mathrm{N}$ uptake by plants; (2) strong deep root system; (3) higher grain filling rate. $\mathrm{Z}$ hold available $\mathrm{N}$ in the soil, moderate nitrification process of ammonia and make it available to plant as needed (Khan et al., 2011). Long slow-release time of $\mathrm{N}$ greatly improved the rice roots morphology and enhanced rice root physiological activity, hence increased $\mathrm{N}$ uptake and rice grain yield (Zhang et al., 2013). $\mathrm{N}$ application with $\mathrm{Z}$ might also increase rice production by improving rice grain filling rate during filling stage. The slow-release fertilizer clearly increased maize average filling rate by 14.18 to $19.32 \%$ and greatly enhanced maize yield by 3.38 to $13.36 \%$ (Ma et al., 2009). In the present experiment, treatment of $\mathrm{N}$ plus $\mathrm{Z}$ resulted in heavier root dry weight and larger $\mathrm{N}$ uptake, and hence obtained obviously higher grain yield. $\mathrm{Z}$ application could also increase the rice grain yield by improving 1000-grain weight in this research. Similar results were found by Sepaskhah and 
Barzegar (2010) and they found Z application could also enhance the rice 1000-grain weight.

\subsection{Effect of Z application with $N$ on $N$ content in plant}

The NUE is very low with an average of $27.15 \%$ in China, which led to a fact that excessive $\mathrm{N}$ in field negatively influenced the quality of environment through leaching and volatilization (Geng et al., 2015; Barea, 2015). The slow-release $\mathrm{N}$ fertilizer used in paddy soil could significantly enhance plant $\mathrm{N}$ uptake and rice grain yield. Using slow-release fertilizer based on the $\mathrm{Z}$ costed less and was easier to apply (Sepaskhah and Barzegar, 2010). In the present study, interaction influences between $\mathrm{Z}$ and $\mathrm{N}$ on NRE, NUE and $\mathrm{N}$ content in plant were observed in two years and it was found that $\mathrm{N}$ application could markedly improve NRE from $\mathrm{N}_{105}$ to $\mathrm{N}_{157.5}$ application rates. This result was in accordance with two researchers who thought NRE was observably increased with increasing $\mathrm{N}$ application from $90-135 \mathrm{~kg}$ ha $^{-1}$ (Timsina et al., 2001; Pirmoradian et al., 2004b). The main reason of $Z$ significantly increasing NRE and NUE at $\mathrm{N}$ application rate of $\mathrm{N}_{105}$ and $\mathrm{N}_{157.5}$ was the higher $\mathrm{N}$ uptake by grain. However, at application rates from $\mathrm{N}_{0}$ to $\mathrm{N}_{52.5}, \mathrm{Z}$ decreased $\mathrm{N}$ content in plant and resulted in non-significant effect on NUE. Similar results were found in crops of Canola Forage and barley (Rehakova et al., 2004; Majid et al., 2012). The dominant causes for the trait may be (1) $\mathrm{N}$ absorption by $\mathrm{Z}$ in exchange sites when $\mathrm{N}$ is available; (2) too long slow-release time of $N$ (Majid et al., 2012). Hao and Zhou (2003) also found that almost $40 \%$ of $\mathrm{NH}_{4}^{+}$in $\mathrm{Z}$ exchange sites was not desorbed based on the following reversible ion-exchange reaction:

$$
\text { Zeolite }-\mathrm{Na}^{+}+\mathrm{NH}_{4}^{+} \square \quad \mathrm{Na}^{+}+\text {Zeolite }-\mathrm{NH}_{4}^{+}
$$
and resulted in $\mathrm{N}$ stress and low $\mathrm{N}$ content in soil (Huang et al., 2010). In this study, the enhanced $\mathrm{N}$ application rates at $\mathrm{N}_{105}$ and $\mathrm{N}_{157.5}$ could alleviate $\mathrm{N}$ stress by $\mathrm{Z}$ for its high absorption capacity to enhance NUE and NRE. At levels of $\mathrm{N}_{0}$ and $\mathrm{N}_{52.5}$, Z application significantly decreased $\mathrm{LNC}, \mathrm{SNC}$ and GNC at the whole rice growth stage based on high absorption capacity. This trait could also explain that $\mathrm{Z}$ input did not significantly affect the rice biomass and $\mathrm{N}$ accumulation when $\mathrm{N}$ was applied at $\mathrm{N}_{0}$ and $\mathrm{N}_{50}$ rates.

\section{Conclusions}

The results herein indicated that both $\mathrm{Z}_{0.22}$ and $\mathrm{Z}_{0.9}$ at appropriate $\mathrm{N}$ application of $\mathrm{N}_{105}$ and $\mathrm{N}_{157.5}$ could greatly enhance rice biomass, dry weight of root, LAI and $\mathrm{N}$ uptake. However, at initial rice growth stage, $\mathrm{Z}$ decreased $\mathrm{N}$ content in plant for its high absorption capacity and hence lowered biomass and $\mathrm{N}$ uptake. There were no significantly differences in rice grain yield with treatment of $\mathrm{Z}$ application from $\mathrm{N}_{0}$ to $\mathrm{N}_{52.5}$. However, at application rates of $\mathrm{N}_{105}$ and $\mathrm{N}_{157.5}, \mathrm{Z}_{0.9}$ and $\mathrm{Z}_{0.22}$ significantly increased rice grain yield by $10.4 \%, 9.2 \%$ and $14.6 \%, 15.3 \%$, respectively. $\mathrm{N}$ and $\mathrm{Z}$ application could markedly improve $\mathrm{NRE}$ at appropriate $\mathrm{N}$ application rates from $\mathrm{N}_{105}$ to $\mathrm{N}_{157.5}$. N mattered little to NUE while $\mathrm{Z}$ application significantly enhanced NUE.

\section{Acknowledgements}

This study was supported by Specialized Research Fund for the Doctoral Program of Higher Education from the Ministry of Education, China (20112103110007) and Special Fund for Agro-scientific Research in the Public Interest from the Ministry of Agriculture, China (201303125).

\section{References}

Barea, J.M. 2015. Future challenges and perspectives for applying microbial biotechnology in sustainable agriculture based on a better understanding 
of plant-microbiome interactions. J. Soil Sci. and Plant Nutr. 15(2), 261-282.

Chen, T. T., Wu, Q., Zheng, J. L., Xu, X. J., Chi, D. C., Sun, D. H. 2014. Effect of water and nitrogen coupling on rice yield based on clinoptilolite. J. Irrig. Drain. Z1, 71-76. (In Chinese)

Fageria, N.K. 2007. Yield physiology of rice. J. Plant Nutr. 30(6), 843-879.

Fitzgerald, M.A, McCouch, S.R, Hall, R.D. 2009. Not just a grain of rice: the quest for quality. Trends Plant Sci. 14(3), 133-139.

Food and Agriculture Organization. 2009. FAO statistics. http://www.fao.org/faostat/en/\#home.

Geng, J.B., Ma, Q., Zhang, M., Li, C. L., Liu, Z. J., Lyu, X. X., Zheng, W. K. 2015. Synchronized relationships between nitrogen release of controlled-release nitrogen fertilizers and nitrogen requirements of cotton. Field Crops Res. 184, 9-16.

Hao, X. Z., Zhou, D. M. 2003. Zeolite application as soil amendment. Soil. 2, 103-106. (In Chinese)

Huang, H. M., Xiao, X. M., Yan, B., Yang, L. P. 2010. Ammonium removal from aqueous solutions by using natural Chinese (Chende) zeolite as adsorbent. J. Hazar. Mater. 175(1), 247-252.

Ippolito, J.A., Tarkalson, D.D., Lehrsch, G.A. 2011. Zeolite Soil Application Method Affects Inorganic. Soil Sci. 176(3), 136-142.

Kavoosi, M. 2007. Effects of zeolite application on rice yield, nitrogen recovery, and nitrogen use efficiency. Commun. Soil Sci. Plant Anal. 38(1-2), 69-76.

Khan, A. Z., KHAN, H., KHAN, R., NIGAR, S., Saeed, B., Gul, H., Amanullah, S., Muhammad, A., Ayub, M., Matsue, N. 2011. Morphology and yield of soybean grown on allophanic soil as influenced by synthetic zeolite application. Pak. J. Bot. 43(4), 2099-2107.
Majid, G., Majid, A., Aria, D., Aydin, K., Hamed, Z. 2012. Decreasing Nitrogen Leaching and Increasing Canola Forage Yield in a Sandy Soil by Application of Natural Zeolite. Agron. J. 104(5), 1467.

Lija, M., Haruna, A. O., Kasim, S. 2014. Maize (Zea mays L.) nutrient use efficiency as affected by formulated fertilizer with Clinoptilolite Zeolite. Emir. J. Food Agric. 26 (3), 284-292.

Ma, C., Wang T. C., Du, Y. Y., Wei, L., Ma, H. P. 2009. Effects of controlled-release nitrogen fertilizer on characteristics of source, sink and flow of summer maize (Zea mays L.). J. Henan. Agric. Univ. 43(5), 480-484. (In Chinese)

Pirmoradian, N., Sepaskhah, A., Maftoun, M. 2004b. Deficit irrigation and nitrogen effects on nitrogenuse efficiency and grain protein of rice. Agron. 24(3), 143-153.

Rehakova, M., Čuvanová, S., Dzivak, M., Rimár, J., Gaval'Ova, Z. 2004. Agricultural and agrochemical uses of natural zeolite of the clinoptilolite type. Curr. Opin. Solid State Mater. Sci. 8(6), 397-404.

Sandhu S.S, Mahal S.S, Vashist K.K. 2012. Crop and water productivity of bed transplanted rice as influenced by various levels of nitrogen and irrigation in northwest India. Agric Water Manage. 104, 32-39.

Sepaskhah, A., Barzegar, M. 2010. Yield, water and nitrogen-use response of rice to zeolite and nitrogen fertilization in a semi-arid environment. Agric Water Manage. 98(1), 38-44.

Shen, Q., Hedley, M., Arbestain, M.C., Kirschbaum, M.U.F. 2016. Can biochar increase the bioavailability of phosphorus? J. Soil Sci. and Plant Nutr. 16(2): 268-286.

Shi, R. H., Bao, S. D. 1996. Soil Agro-chemistrical Analysis. Beijing agricultural press, Beijing. 
Tang, S. H., Xu, P. Z., Chen, J. S., Ai, S. Y., Zhang, F. B., Huang, Y. 2007. Effects of single basal application of controlled-release fertilizer on root activity and nutrient absorption of rice (Oryza SatavaL.). Plant Nutr. Fert Sci. 3(4), 591-596. (In Chinese)

Timsina, J., Singh, U., Badaruddin, M., Meisner, C., Amin, M.R. 2001. Cultivar, nitrogen, and water effect on productivity, and nitrogen-use efficiency and balance for rice wheat sequences of Bangladesh. Field Crop Res. 72, 143-161.
Zahedi, H., Noormohammadi, G., Rad, A. S., Habibi, D., Boojar, M. A. 2009. Effect of Zeolite and Foliar Application of Selenium on Growth, Yield and Yield Component of Three Canola Cultivar under Conditions of Late Season Drought Stress. Not. Sci. Biol. 1 (1), 73-80.

Zhang, W. M., Meng, J., Wang, J. Y., Fan, S. X., Chen W. F. 2013. Effect of Biochar on Root Morphological and Physiological Characteristics and Yield in Rice. Acta Agron. Sin. 39(8), 1445-1451. 